\title{
Competence Approach to the Development of Modern Public Administration: Theory and Practice of Implementation
}

\author{
Marta Karpa ${ }^{1 *[0000-0001-8141-4894]}$, Oleksandr Akimov 2 [0000-0002-9557-2276] \\ ${ }^{1}$ Vasyl Stefanyk Precarpathian National University, Ivano-Frankivsk, Ukraine \\ ${ }^{2}$ Interregional Academy of Personnel Management, Kyiv, Ukraine \\ "marta.karpa@ukr.net
}

\begin{abstract}
The article proposes to apply the competence approach to the development of modern public administration. The public administration object are the the interests of social institutions in the common territory, which have different interests and goals. The problem of defining and allocating public functions as prerequisites for defining and forming the competences of public institutions is analyzed. The result of applying the competence approach is the institutional consolidation of functions in the context of the existence of the main models of the territorial organization of power. Trends in the development of the competence approach in the context of the practice and theory of public administration are analyzed. It is concluded that modern concepts of public administration are characterized by a shift in the balance between state and public institutions in the sphere of common goals and objectives, and, accordingly, responsibility. The public activity of all subjects of society is determined through the implementation of new forms of cooperation, the definition of spheres and subjects of activity of each subject for effective cooperation, the distribution of functions and competencies of the subjects, the formation and consolidation of their status characteristics. The general sphere of competence of local self-government has been determined, which defines the basic principles of powers and functions for local self-government. The limits of competence of public authorities are analyzed in the context of the analysis of the European Charter of Local Self-Government. It is provided to summarize the general competence of public authorities through the implementation of their main functions and tasks.
\end{abstract}

Keywords: public administration, public service, competence, competence approach, theory of public administration.

\section{INTRODUCTION}

The issue of defining the interests of social institution in a common territory that have different interests and goals is relevant today. The basis for many concepts and theories today is the implementation of management in the interests of both humanity as a whole and each individual person with the possibility of preserving and increasing the efficiency of using available resources. The combination of state, self-governing and public interests, and, according to them, the definition and implementation of certain functions, sets new tasks for the science and practice of public administration in terms of their scientific definition and practical implementation.
In the dynamics of the formation and development of popular theories of the interaction of state and local authorities, such as the theory of a free community, public and public-state (theory of municipal dualism), a number of characteristic features of competence approaches can be traced, which are manifested both through general theoretical relationships and manifestations, and through the practice of coexistence of public authorities. The problem arises of the definition and distribution of public functions as a prerequisite for the definition and formation of the competences of public institutions. An important issue in the context of the competence approach is the institutional consolidation of functions in the context of the existence of the main models of the territorial organization of power. 
Representatives of various foreign scientific schools, namely G. Breban, J. Wedel, D. Garner, J. Grimaud, C. Davis, J. Eberbach, K. Eckstein, J. Elder, N. Owen, S. Solon, R. Schaffhauser, J. Chevalier and others.

\section{PREREQUISITES \\ FOR THE DEVELOPMENT OF THE COMPETENCE APPROACH IN THEORY AND PRACTICE OF PUBLIC ADMINISTRATION}

According to a number of researchers, the competence paradigm emerged in the 70s of the twentieth century. The development of a competence approach as a systemic concept for describing a person's education is linked with the research of the famous American linguist N. Chomsky, who formulated the concept of competence in relation to the theory of language [1]. As the dominant educational paradigm, the competence approach began to develop in the late 70s. under the influence of the formation of educational models in Western Europe and the United States [2].

A prerequisite for this can be considered the development of public policy as a subject of scientific research, which took place in the late 1960s, when the American Scientific Council for Public Research held two conferences and published a collection of scientific articles edited by Austin Rennie. In 1972 the Organization for Policy Research was created, began to increasingly attract the attention of scientists to the study of problems in the field of public administration. Formed in 1920-1930, the think tank "Political and Economic Planning" in Great Britain merged in 1976 with the Center for Social Planning Research to form the Institute for Public Policy Research. Public policy analysis began to be actively addressed in the middle of the twentieth century. Scientists of that time considered the main motives for the implementation of public policy to be "public interest" and "public good." The content of these concepts is interpreted as follows: "a public good is something that is produced by the state, not the market." development trends, the study of new forms of statehood is increasing, the distance between society and the state is shrinking, transnational and other globalization movements are emerging. [3] Researchers record the growth of conflict between the state and society. In the world, the 60-70s of the twentieth century are considered the apogee of the development of all state institutions. society requires new forms of power relations, new management agreements. Scientists-globalists are promising in the context of historical development, socio-economic progress and democratization to respect civil states of multi-ethnic nations and democratic states of social partnership [4].

The main components of public power are state and self-governing, which address many issues in a comprehensive manner, taking into account their capabilities (powers). It is very difficult to single out one component and carry out its reforms, because they are often linked by common tasks, certain funding, etc. Therefore, public authorities should be considered only taking into account consistency, as its basic characteristics. The main features of public power are: the possibility of expressing the will of the people (taking into account public opinion, developing a mechanism for such accounting), serving the government to the people, interaction between the government and the people on an equal footing. "... The public, - according to the definition of the world famous German social philosopher J. Habermas, is an environment in which a polyphonic process of creating opinions takes place, where strength is replaced by mutual understanding" [5].

Society constantly generates conflicts, for the settlement of which it is necessary to conclude deals. Therefore, the main instruments for regulating disputes between the state and society should be consultations, negotiations, public hearings, round tables and other processes of agreements with the state that are open to society. "Public administration - as defined by George G. Sebine and Thomas L. Thorson, is primarily a system of institutions, designed to regulate public opinion and debate, and take into account opposite requirements in order to develop an effective policy" [6].

If in the past idealized models in many countries that have embarked on the path of "new government" were promoted as efficient markets for public services, now this "best path" is being questioned and forms alternatives, for example, Governance (Good Governance, Global Governance) - "interorganizational perspective instead of intraorganizational; reorganization of cooperative relations of actors in the public, private and third sectors; network structures instead of the market and hierarchy; combination of forms of management (public-private partnership, coproduction)" [7].

Distributed since the 90s. the concept of Governance, which was formed after the publication of the work of $\mathbf{J}$. Habermas "Theory of Communicative Action" [8] in the 90s. XX century, is characterized by partnership principles of interaction, forms the institutional consolidation of relations between government, business and citizens. This is often interpreted as an equal partnership, which should mean the same right of access to resources. At the same time, in the competence aspect, the issues of establishing the norms of responsibility, the distribution of powers, and, consequently, endowing the participants with an appropriate status remain difficult. The basis of the concept remains relevant in the future, although the primary source of its creation was the exercise of power in the process of managing the political, economic and social resources of countries, to carry out the transition from totalitarian to democratic regimes, was considered an instrument of the World Bank from 1993 [9]. 
In each of the varieties of the Governance concept, the specificity of the use of competence components. The concept of Responsive Governance manifests itself in terms of responsibility as a component of the competence of management subjects. The concept of Democratic Governance is manifested in the context of the formation and consolidation of the status characteristics of all subjects of governance as equal participants, forms power powers, departmental structure and responsibility. Most of the attention is focused on the concept of Good Governance - good / good governance, which implies the involvement of business and the public in governance processes, the basis of which is human rights, interaction between various institutional levels. All types of the Governance concept expand the participation of its subjects in public administration, including among citizens, public organizations, institutions and business structures. Strengthening public control creates certain competence restrictions on government institutions or even self-government institutions [10].

\section{INSTITUTIONALIZATION OF COMPETENCIES OF PUBLIC AUTHORITIES}

A number of factors affect the development and functioning of the civil service, including: legal, organizational, structural and functional, information related to resources, and the like. Of course, institutional factors are also important as a prerequisite for the institutional dimension of public service. The issue of institutional factors encompasses a wide range of scientific research, ranging from establishing causality and analyzing the competence of civil service institutions.

The institutional relationship between the public and private sector was investigated by T. Veblen [11]; the institutional issues of the relationship of market mechanisms in the field of public administration and the possibility of the emergence of monopolies in cooperation with public administration authorities were investigated by R. Coase [12].

In the process of studying and applying the institutional framework in the field of the functioning of public services, there is an ambiguous understanding and use of a number of concepts that require clarification and analysis. Among them: institution, state institution, state institution, institution, institutionalization, institutional framework, institutional resource, institutional factor, etc. [13].

The functioning of social institutions is often viewed by scientists as relatively independent components of social institutions, creates a certain system. According to another approach, the institution is viewed as a functional model of specific organizations, which determines their status and common institutional characteristics. A public service that functions as a process can be seen in the light of a significant number of institutions. In order to understand the essence of the institution of public service in the system of state institutions, there is a need to determine the essence of its institutional subject, the nature of the power that it, levers and tools for its implementation.

The generalized definition of public service is considered as follows: public service is a complex institutional complex that allows regulating the social life of society and aimed at meeting the interests of all subjects of state power. Public service is viewed as an organizational and managerial institution, legal, cultural, social, economic, informational and other institutions.

There are some institutional factors that ensure the functioning of the civil service:

- legislative strengthening of the functioning of civil service institutions within the functioning of the civil service institution;

- the degree of separation of institutions as independent entities identified in the legislative, organizational, and functional context;

- institutional independence of the subjects of the implementation of state power;

- institutional balance of subjects.

Further scientific research may concern the development of a theoretical and methodological basis for the implementation of effective institutional reforms, overcoming institutional differences in the practice of public administration.

The position, from the moment of her employment, provides the civil servant with the appropriate legal, social, organizational and functional status. In the "status-competence-activity-service" scheme, the fact of occupying a position is a prerequisite for obtaining the corresponding status characteristics, and allows you to continue moving along the scheme. The competence of local government officials is determined by the structure of government, the typical professional and qualification characteristics of local government officials and the regulations of the institution. The special competence of officials should be reflected in the job description, where it is necessary to clearly highlight the place and role of an official of local government in the activities of the unit, the limits of his powers, relations in accordance with the position, rights, duties, obligations, guarantees, motives and restrictions, conditions for effective work.

The European Charter of Local Self-Government formulates the principles defining the nature and scope of the competence of local self-government and ensuring the autonomy of local authorities (Articles 2-11). The sphere of competence of local self-government according to the European Charter of Local Self-Government [14], 
which came into force for Ukraine from 01.01.1998r. formulated in such basic principles (Article 4):

1. The main powers of local self-government institutions are determined by the constitution or law. However, this provision does not preclude the granting of powers and functions to local governments for special purposes in accordance with the law.

2. Institutions of local self-government, within the limits of the law, have every right to freely decide any issue that is not excluded from their sphere of competence and is not assigned to any other institution.

3. Public powers, as a rule, should be predominantly vested in the public authorities closest to citizens. When delegating certain powers to another institution, it is necessary to take into account the scope and nature of the task, as well as the requirements for efficiency and economy.

4. The powers vested in local self-government institutions, as a rule, should be full and exclusive. They cannot be canceled or limited by another, central or regional authority, unless provided by law.

5. When delegating powers to local self-government institutions by a central or regional institution, local selfgovernment institutions, as far as possible, have the right to adapt their activities to local conditions.

6. In planning and making any decisions directly related to local governments, consult with, as far as possible, in a timely and appropriate manner.

The explanatory commentary to the European Charter of Local Self-Government (1996, Strasbourg) states that the exercise of public powers should be decentralized. This principle found its place in many documents adopted within the framework of the Council of Europe, in particular in the conclusions of the Lisbon Conference of European Ministers Responsible for Local Governance, which took place in 1997. This principle means that an issue that is not one that requires a solution within a large territorial entity or is not a priority given the achievement of efficiency or economy, should be left within the powers of the governing institutions of the basic level. The fourth point reveals the problem of overlapping powers. It is pointed out that in order to clearly define and avoid any tendencies towards a gradual dispersion of responsibility, for this the powers should be full and exclusive. However, in some areas there is a need for joint actions of different levels of government. At the same time, it is important that in such cases the intervention of central or regional authorities takes place in strict compliance with the law.

Clause 5 indicates that the administrative structures of local self-government institutions and their proximity to local realities can facilitate the performance of certain functions, the main responsibility for which lies with the highest levels of government. There is also the importance of taking local realities into account when exercising delegated authority. However, the existence of unified rules is recognized, does not leave the freedom to act at its own discretion.

The next paragraph is devoted to issues that are both within the competence and outside of it, but directly concern local governments. It is assumed that the method and timing of consultations should be determined in such a way that local governments have a real opportunity to influence the outcome of resolving issues, while admitting that extraordinary circumstances, for example, the need for urgent decision-making, may impede consultations [15]. Thus, the coordination principle of establishing the competences of public authorities is enshrined. Particularly noteworthy is the principle proposed by the Council of Europe: issues that, on the one hand, are not excluded from the competence of local governments, and on the other, are not entrusted to state authorities, should be resolved by local governments.

\section{CONCLUSION}

On the development trends of competence approaches in the context of practice and theory of public administration, it is determined that modern concepts of public administration are characterized by a shift in the balance between state and public institutions in the sphere of common goals and objectives, and, accordingly, responsibility. The joint activity of all subjects of society requires new forms of cooperation, the definition of spheres and subjects of activity of each subject for effective cooperation, the distribution of functions and competencies of the subjects, the formation and consolidation of their status characteristics.

A certain area of competence of local selfgovernment can be considered general, such as defining the basic principles of powers and functions for local selfgovernment. The boundaries of competence of public authorities in the context of the analysis of the European Charter of Local Self-Government can be established taking into account the following basic criteria $[16 ; 17 ; 18]$ :

- legal criterion for the delineation of powers. The law can be most directly exercised at the local level. It is noted that the principle of local self-government should be recognized in national legislation and, as far as possible, in the constitution (Article 2). Local selfgovernment is understood as the right and real ability of local self-government institutions, within the framework of the law, to regulate and manage a significant share of public affairs, under their own responsibility and in the interests of the local population (Article 3). The main powers of local governments are determined by the constitution or law (Article 4);

- the financial criterion for the delineation of powers. The issue of determining and regulating the financial sphere of local self-government activities is defined in 
Article 9 "Financial resources of local self-government institutions". According to this criterion, the amount of financial resources of local self-government institutions must correspond to the powers granted to them by the Constitution or by law. The practice of public administration of the world unitary states shows that regional institutions do not carry out financial equalization from the structural units of the territorial structure of the state, local networks [19];

- organizational criterion for the delineation of powers. One of the methods to achieve this goal is to conclude agreements in the field. Articles 6 and 7 define the appropriate administrative structures and resources for local governments to carry out their tasks and the conditions under which local authority is exercised. Article 8 defines the basic principles for the implementation of administrative supervision over the activities of local government institutions [20;21;22].

In general, the main expected results of applying the competence approach in the field of public administration were identified:

- setting the boundaries of the competence of public service entities (public authorities, their officials);

- improvement of the legal and regulatory framework in terms of establishing and delineating the competences of subjects of public administration;

- increasing the level of public confidence in the activities of public authorities and public officials;

- reducing the cost of performing public functions;

- the formation of a corporate culture in public authorities and in the activities of public officials [23-25].

The next conclusion is that a prerequisite for determining the general competence of public authorities is their main functions and tasks. And between the relationship "function-status" from the position of the competence approach, there is often a gap in terms of resolving issues of powers, rights, duties, responsibilities, subjects of jurisdiction, jurisdiction - that is, the main components of the competences of public authorities. So, it seems expedient to propose the scheme "function competence - status - activity" as more accurate in terms of building the theoretical foundations of the competence approach in public administration and logical for the practice of implementation in the development of legal regulation of management processes.

\section{REFERENCES}

[1] The official site of Noam Chomsky (2020), available at: https://chomsky.info.

[2] Simchenko, N.O. (2012), Ways of realizing competence in the management of human resources, available at: http://nauka.kushnir.mk.ua/?p=26165.

[3] Parsons, V. (2006), Public Policy: Introduction to the Theory and Practice of Policy Analysis: Translated from English, Kyiv, Kyiv-Mohyla Academy Publishing House, 549 p.

[4] Belarus, O.G. Lukyanenko, D.G. and others (2001), Globalization and security of development, Kyiv, KHEU, 733 p.

[5] Habermas, Y. (1995), Democracy, reason, morality, Moscow, Russia, p. 40

[6] Sebain, G.G. and Thorson, Th.L. (1997), History of Political Thought, Kyiv, Osnovy, pp. 650-651.

[7] R'ober, M. (2007), “Governance”, Dopovid' u Natsional'nij Akademii derzhavnoho upravlinnia pry Prezydenti, October 22.

[8] Habermas, J. (1981), Theorie des kommunikativen Handelns, 524 p.

[9] Traité de Lisbonne modifiant le traité sur l'Union européenne et le traité instituant la Communaute europeenne, signé (2007), Journal officiel de l'Union europeenne, vol. 17, 306 p.

[10] Karpa, M.I. (2018), “Competence approach in European public administration: essence and tendencies of development (archetypal dimension)", Public administration, Issue 4 (14), pp. 132-143.

[11] Veblen, T. (1984), Teorija prazdnogo klassa [The Theory of the Leisure Class], Moscow, Progres, Russian, available at: https://drive.google.com/file/d/0B94jiYiyxxDHU W9QeWxDVk9LMDA/view.

[12] Coase, R.H. (1960), "The Problem of Social Cost The Journal of Law \& Economics", The University of Chicago Press.

[13] Karpa M.I., Akimov, O.O. Troschinsky, V. Stefanyk, V. and Ventsel, V. and Akimova, L.M. (2020), "Intrenational Experience of the Public Administration in the Area of National Security", Journal of Legal, Ethical and Regulatory, Issues (23).

[14] European Charter of Local Self-Government. Council of Europe (1985), available at: http://zakon3.rada.gov.ua/laws/show/994_036. 
[15] Karpa, M.I. Levytska, S.O. Akimova, L.M. Zaiachkivska, O.V. and Gupta, S.K. (2020), Modern Analytical Instruments for Controlling the Enterprise Financial Performance. Collection of scientific papers Financial and Credit ActivityProblems of Theory and Practice, № 2 (33), pp. 314-323.

[16] Karpa, M.I. (2016), "To the analysis of the sphere of competence of public authorities (according to the European Charter of Local Self-Government)", Materials of the fifth annual scientific-practical conference, Odessa, ORIDU NADU.

[17] Akimova, L. M. Reinska, V. B. Akimov, O. O. and Karpa, M. I. (2018), "Tax preferences and their influence on the investment in Ukraine", Financial and Credit Activity-Problems of Theory and Practice, №3(26), pp. 91-101. DOI: 10.18371/FCAPTP.V3I26.144117.

[18] Akimova, L.M. Levytska, S.O. Pavlov, K.V. Kupchak, V.R. \& Karpa (2019), "The role of accounting in providing sustainable development and national safety of ukraine", Financial and credit activity: problems of theory and practice, № $30 \quad$ (3), $\quad$ pp. $\quad 64-70 . \quad$ DOI: 10.18371/FCAPTP.V3I30.179501.

[19] Kostiukevych, R. Mishchuk, H. Zhidebekkyzy, A. Nakonieczny, J., \& Akimov, O.O. (2020), “The impact of European integration processes on the investment potential and institutional maturity of rural communities", Economics and Sociology, № 13 (3), pp. 46-63. DOI:10.14254/2071789X.2020/13-3/3

[20] Zahorskyi, V.S. Lipentsev, A.V. Mazii, N.H. Bashtannyk, V.V. \& Akimov, O.O. (2020), "Strategic directions of state assistance to enterprises development in Ukraine: managerial and financial aspects", Collection of scientific papers Financial and Credit Activity-Problems of Theory and Practice., №2(33), pp. 452-462. DOI: https://doi.org/10.18371/fcaptp.v2i33.207230.

[21] Zahorskyi, V.S., Lipentsev, A.V., Yurystovska, N.Ya., Mazii, N.H., \& Akimov, O.O. (2019), "Financial and administrative aspects of small business development in Ukraine", Financial and Credit Activity-Problems of Theory and Practice. № 3(30), pp. 351-360. DOI: https://doi.org/10.18371/fcaptp.v3i30.179717.

[22] Kapan Oralgazyolu Shakerkhan, Ermek Tolegenovich Abilmazhinov (2019), "Development of a Method for Choosing Cloud
Computing on the Platform of Paas for Servicing the State Agencies", International Journal of Modern Education and Computer Science, №9, pp. 14-25. DOI: 10.5815/ijmecs.2019.09.02.

[23] Olaniyan Joseph Olawale, Ademuyiwa A. Justus (2019), "Comparative Analysis of Personnel Distributions in the Local Government Service in Ekiti-State, Nigeria, for Service Delivery", International Journal of Mathematical Sciences and Computing, № 2, pp. 44-53. DOI: 10.5815/ijmsc.2019.02.04.

[24] Vickky Listyaningsih and Ema Utami (2018), "Decision Support System Performance-Based Evaluation of Village Government using AHP and TOPSIS Methods: Secang Sub-district of Magelang Regency as a Case Study", International Journal of Intelligent Systems and Applications, № 4, pp. 18-28. DOI: 10.5815/ijisa.2018.04.03.

[25] Balakumaran P.J and Vignesh Ramamoorthy. H. (2013), "Evolving An E-Governance System for Local Self-Government Institutions for Transparency and Accountability", International Journal of Information Engineering and Electronic Business, № 6, pp. 40-46. DOI: 10.5815/ijieeb.2013.06.05. 